Petra de Goeij • Pieter J.C. Honkoop

\title{
Experimental effects of immersion time and water temperature on body condition, burying depth and timing of spawning of the tellinid bivalve Macoma balthica
}

Received: 18 January 2001 / Accepted: 5 August 2002 / Published online: 11 October 2002

C) Springer-Verlag and AWI 2002

\begin{abstract}
The burying depth of many bivalve molluses on intertidal mudflats varies throughout the year and differs between places. Many factors are known to influence burying depth on a seasonal or spatial scale, with temperature and tidal regime probably being very important. Burying depth, body condition and gonadal development of Macoma balthica were followed throughout winter and spring in an experiment in which water temperature and immersion time were manipulated. Unexpectedly, relative water temperature, in contrast to the prediction, did not generally affect body condition or burying depth. This was probably a consequence of the exceptionally overall low water temperatures during the experimental winter. Differences in temperature did, however, result in different timing of spawning: $M$. balthica spawned earlier at higher spring temperatures. Longer immersion times led to higher body condition only late in spring, but led to deeper burying throughout almost the whole period. There was no effect of immersion time on the timing of spawning. We conclude that a longer immersion time leads to deeper burying, independent of body condition. We also conclude that burying behaviour of $M$. balthica is not determined by the moment of spawning.
\end{abstract}

Keywords Feeding - Gametogenesis · Risk taking · Timing of reproduction $\cdot$ Wadden Sea

Communicated by E. Rachor

P. de Goeij ( $)$ P.J.C. Honkoop

Netherlands Institute for Sea Research (NIOZ), PO Box 59,

1790 AB Den Burg, Texel, The Netherlands

e-mail: petra@nioz.nl

Tel.: +31-222-369300, Fax: +31-222-319674

Present address:

P.J.C. Honkoop, Special Research Centre

for Research on Ecological Impacts of Coastal Cities,

Marine Ecology Laboratories A 11,

University of Sydney, NSW 2006, Australia

\section{Introduction}

The tellinid bivalve Macoma balthica shows a seasonal pattern in burying depth. M. balthica live deepest in winter, bury shallower in spring, and deeper again in summer (Reading and McGrorty 1978; Zwarts and Wanink 1993). The actual burying depths vary considerably between years (Zwarts and Wanink 1993). Additionally Hulscher (1973) found that M. balthica low in the intertidal buried deeper than $M$. balthica high in the intertidal. There are many factors that can influence burying depth. Burying depth is correlated with body condition (Zwarts and Wanink 1991) and with siphon mass (Zwarts and Wanink 1989). The better the body condition, the deeper the bivalves are buried, and the longer the siphon, the deeper they are buried. Burying depth in $M$. balthica also seems to be influenced by feeding conditions. Lin and Hines (1994) showed that when the concentration of suspended algae in the water decreased, M. balthica switched from suspension feeding to deposit feeding and therefore moved closer to the surface. De Goeij and Honkoop (2002) showed experimentally that shorter immersion time led to shallower burying, presumably because time for suspension feeding was shorter and $M$. balthica had to compensate for this with deposit feeding.

Honkoop and Beukema (1997) experimentally demonstrated that when water temperatures in winter were lower and when body condition of $M$. balthica in the previous autumn was higher, body condition score of $M$. balthica in early spring was higher. The findings of Zwarts and Wanink (1991) and Honkoop and Beukema (1997) together suggest that colder winter water temperatures must lead to a higher body condition, and that this higher body condition could lead to deeper buried $M$. balthica in spring. Deeper burying in spring would mean a higher chance of survival, since burying deep provides safety against probing avian predators (Zwarts and Wanink 1993).

M. balthica spawns in the Wadden Sea in spring (Caddy 1967; Lammens 1967; Honkoop and van der 
Meer 1997). Because this is also the period in which M. balthica is buried at its shallowest, spawning itself may force the animals to the surface.

For many predators on the intertidal flats the accessibility of their prey is of major importance. For example Zwarts and Wanink (1993) showed that fluctuations in burying depth of $M$. balthica was the main source of variation in biomass that could actually be harvested by red knots, Calidris canutus. In the present study we aim to throw some light on the factors that determine the accessible fraction of $M$. balthica in spring, a time of the year that red knots and other predatory shorebirds depend on them.

The first objective of this study is to experimentally test whether immersion time and water temperature influence burying depth of $M$. balthica from late winter to spring. The second objective is to test whether different burying depths are mediated by differences in body condition. The third objective is to find out whether burying behaviour in $M$. balthica is related to the timing of spawning.

\section{Methods}

\section{Practical set up}

We used the same experimental set-up as Honkoop and Beukema (1997). Briefly, the experimental set-up consisted of four doublewalled and isolated basins $(1 \times \mathrm{w} \times \mathrm{h}=265 \times 77 \times 61 \mathrm{~cm})$. A small part of each basin at the inlet side was used to adjust water temperature by either heating or cooling it. This part was separated from the rest of the basin by a wooden partition. Sea water pumped out of the Wadden Sea entered the inlet at a rate of $61 \mathrm{~min}^{-1}$. Cooled, heated, or untreated, it flowed over the wooden partition into the rest of the basin. Along its length the basin was divided into two compartments with different heights ('subtidal' and 'tidal'), each with an area of $0.65 \mathrm{~m}^{2}$ (see Fig. 2 in Honkoop and Beukema 1997). We used sand without organic material with a median grain size of $291 \mu \mathrm{m}$. The depth of the sediment layers was $17 \mathrm{~cm}$ in the subtidal and $30 \mathrm{~cm}$ in the intertidal area. To avoid temperature peaks due to solar radiation, and also to avoid growth of macroalgae, the basins were covered with a $4 \mathrm{~cm}$ layer of opaque isolating material.

\section{Design and statistical analyses}

Two replicate plots (basins) were used for each of two temperature levels. Each of these four plots was divided into the two previously mentioned compartments, one tidal and one subtidal. This "split plot" design (Cochran and Cox 1957) was statistically analysed with the appropriate ANOVA procedures in SYSTAT 7 (SPSS 1997). The effect of temperature (1 $d f)$ was tested using the plots within each temperature $(2 d f)$ as the error term. For the effects of tidal regime $(1 d f)$ and the interaction between temperature and tidal regime $(1 d f)$, the tidal regime by plots within each temperature $(2 d f)$ was used as the error term. Because of the low power of the experimental set-up (only one replicate per treatment), significance levels were set to $\alpha=0.1$.

\section{Temperature regime}

The starting point of the temperature regime in the experimental basins was the water temperature of the nearby Marsdiep tidal inlet. Because the set-up was placed outdoors and was fed with

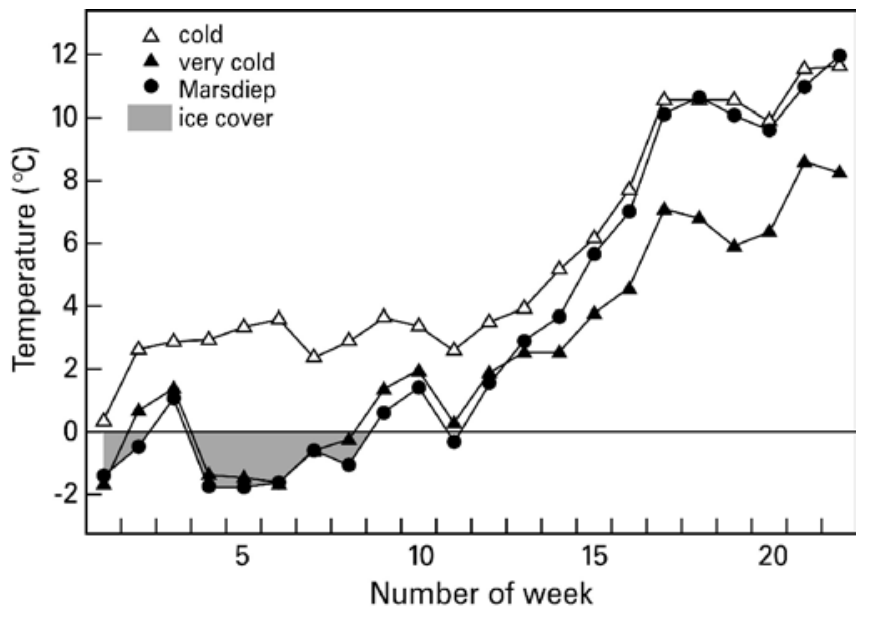

Fig. 1 Weekly mean water temperatures of the Marsdiep inlet, where the water from the experimental set-up was taken from, and weekly mean water temperatures for the two 'very cold' basins and the two 'cold' basins, during the period 1 January to 29 May 1996. Note that at water temperatures below about $0^{\circ} \mathrm{C}$ the basins were iced

Marsdiep water, the temperature of the inflowing water fluctuated with the water temperature of the Marsdiep inlet (Fig. 1). The aim was to simulate a 'mild' and a 'cold' winter, but since the winter of 1995/1996 was very cold we have simulated a 'cold' and 'very cold' winter. The water in two out of four basins was heated to simulate the 'cold' winter and the temperature of the water of the other two basins remained unchanged to simulate a 'very cold' winter. By 20 March the temperature of the seawater had become so warm that we stopped heating the 'cold' basins and started to cool the 'very cold' basins.

\section{Tidal regime}

The water level, and thus the time available for pelagic feeding, was manipulated manually by changing the height of the outlet overflow. During weekdays, the water was lowered to $11 \mathrm{~cm}$ above the subtidal area (low water level, LWL) from 0800 hours to 1700 hours, thus exposing the higher ('tidal') level. Once per week the water level was also kept low during the night. In this way the simulated low water level was maintained for $72 \mathrm{~h}$ a week, having a low tidal level for $43 \%$ of the time. The water level during the remaining part of the week $(96 \mathrm{~h})$ was kept $17 \mathrm{~cm}$ above LWL, resulting in submersion of both levels. The winter of 1995/1996 happened to be a very cold winter (see Fig. 1). Ice covered the 'cold winter' basins on two occasions. To prevent the animals from freezing during these two frost periods, the $M$. balthica were kept continuously submerged in all basins.

\section{Burying depth, body mass, and gonadal development measures}

From 13 to 15 December 1995, M. balthica with shell lengths between 14 and $17 \mathrm{~mm}$ were collected on an intertidal flat in the Wadden Sea at Balgzand. Shell length of each individual bivalve was measured with electronic calipers to the nearest $0.1 \mathrm{~mm}$. A nylon thread of known length with a numbered tag was attached to each bivalve with adhesive and a small sticker (for a detailed description, see Zwarts 1986). On 19 December, 150 tagged bivalves were put on top of the sediment in each experimental plot where they could bury themselves. From 18 February to 29 May 1996 the burying depth of 60-100 individual bivalves was measured six times. The depth to which a bivalve buried could be calculated by measuring the length of the thread remaining above the sediment surface. 
Fig. 2 Changes in body mass index (BMI) of Macoma balthica in the experimental set-up. Mean BMI values of 15 animals per plot per treatment were plotted. Each line connects the BMI value of the intertidal and subtidal group for each plot. For each sampling day the temperature ( $V C$ very cold, $C$ cold) and the immersion treatment ( $t$ intertidal, $s$ subtidal) are indicated. The $Y$-axis shows the BMI values expressed as $M / L^{3}$ ( $M$ ash free dry mass in milligrams, $L$ shell length in centimetres). Below each part of the figure, ANOVA results are given. Significance levels are shown as $* *$ if $P<0.05$ and $*$ if $P<0.10$

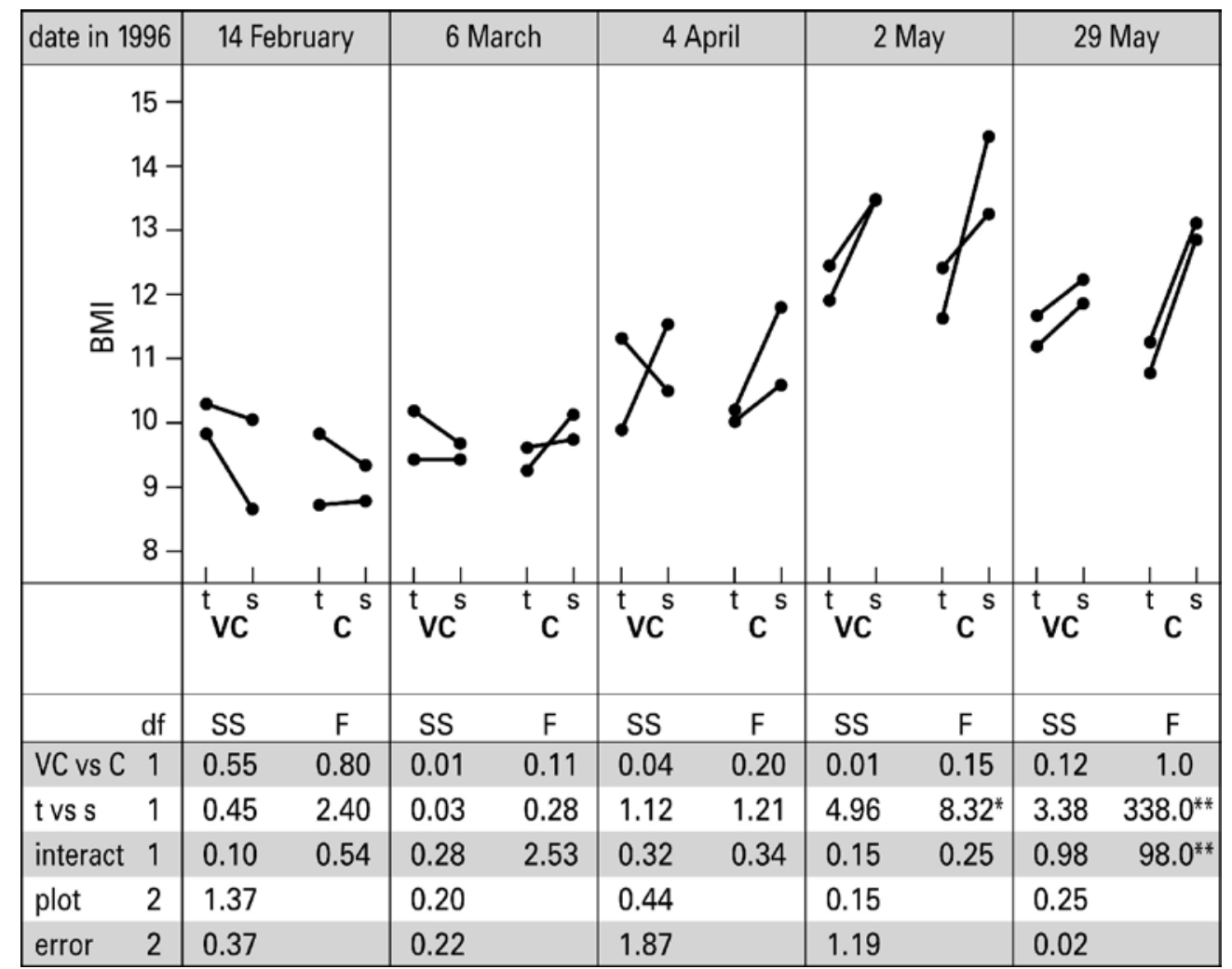

After each depth measurement, with the exception of 17 March, $15 \mathrm{M}$. balthica were taken randomly from the plots to determine their body mass index (BMI) and gonadal development. To determine BMI (the mass of the bivalve corrected for shell size), the soft parts were separated from the shell. Shell length of each individual bivalve was measured with electronic calipers to the nearest $0.1 \mathrm{~mm}$. Ash-free dry mass (AFDM) was determined by drying the soft parts for 4 days at $60^{\circ} \mathrm{C}$, weighing the samples to the nearest $0.01 \mathrm{mg}$, incinerating for $5 \mathrm{~h}$ at $580^{\circ} \mathrm{C}$ and then weighing them again after cooling to room temperature. The difference between dry mass and ash mass after incineration represents ash free dry matter (AFDM). The body mass index is expressed as total AFDM per cubic shell length $\left(\mathrm{mg} \mathrm{cm}^{-3}\right)$.

Gonadal development was recorded by looking at the freshly opened bivalve. The gonadal stages were examined macroscopically and five scores were assigned, from completely full of eggs or sperm $(=1)$ to empty $(=0)$ with three stages in between. A gonad index was calculated for each treatment group by adding all individual scores within the same treatment and dividing this by the total number of $M$. balthica in the particular treatment.

\section{Results}

\section{Water temperatures}

With a mean water temperature of $0.1^{\circ} \mathrm{C}$ (Fig. 1) the Marsdiep waters were exceptionally cold during JanuaryMarch 1996. The mean Marsdiep winter temperature for the period $1970-1995$ was $4.1^{\circ} \mathrm{C}$. The mean temperature of the four coldest years in that period was $1.5^{\circ} \mathrm{C}$ and of the four mildest years $6.1^{\circ} \mathrm{C}$ (Honkoop and Beukema 1997). As a result of the severe winter conditions in 1996, the simulated temperature regimes in the experiment were similar to a 'very cold' $\left(0.3^{\circ} \mathrm{C}\right)$ and 'cold' $\left(3.1^{\circ} \mathrm{C}\right)$ winter. The 'very cold' basins had ice coverage for two periods. From the beginning of April onwards water temperatures in the 'very cold' basins were higher than $4^{\circ} \mathrm{C}$, the temperature above which $M$. balthica are able to grow (Beukema et al. 1985). In the 'cold' basins, water temperatures were between $2^{\circ} \mathrm{C}$ and $4^{\circ} \mathrm{C}$ until mid-March. Then temperatures started to increase (Fig. 1).

The effect of water temperature on body mass index, burying depth and gonadal development

There were no significant differences in body mass indices of M. balthica subjected to the 'very cold' and 'cold' treatments (Fig. 2). A significant effect of water temperature on burying depth was only observed on the first and the last date of sampling. On 13 February, M. balthica subjected to the 'cold' treatment buried significantly deeper than the ones subjected to the 'very cold' treatment. On 29 May the direction of the effect of temperature was the opposite; in the 'very cold' treatment the bivalves were buried deeper than in 'cold' treatment (Fig. 3). On the three first sampling dates the gonads of all examined $M$. balthica were completely filled with gametes. The gonads extended all over the stomach and the intestines. On 2 May the first animals had released gametes (Fig. 4). In the 'cold' basins significantly more $M$. balthica had released gametes than in the 'very cold' basins. On 29 May more than 50\% of the bivalves in the 'cold' basins had released their sperm or eggs. In the 'very cold' basins this percentage was significantly lower. 
Fig. 3 Changes in burying depth $(\mathrm{cm})$ of Macoma balthica in the experimental set-up. Mean burying depths of 60-100 animals per plot per treatment were plotted. Each line connects the burying depth of the intertidal and subtidal group for each plot. For each sampling day the temperature $(V C$ very cold, $C$ cold) and the immersion treatment ( $t$ intertidal, $s$ subtidal) are indicated. The $Y$-axis shows the burying depth in centimetres. Below each part of the figure, AN-

OVA results are given. Significance levels are shown as ** if $P<0.05$ and * if $P<0.10$

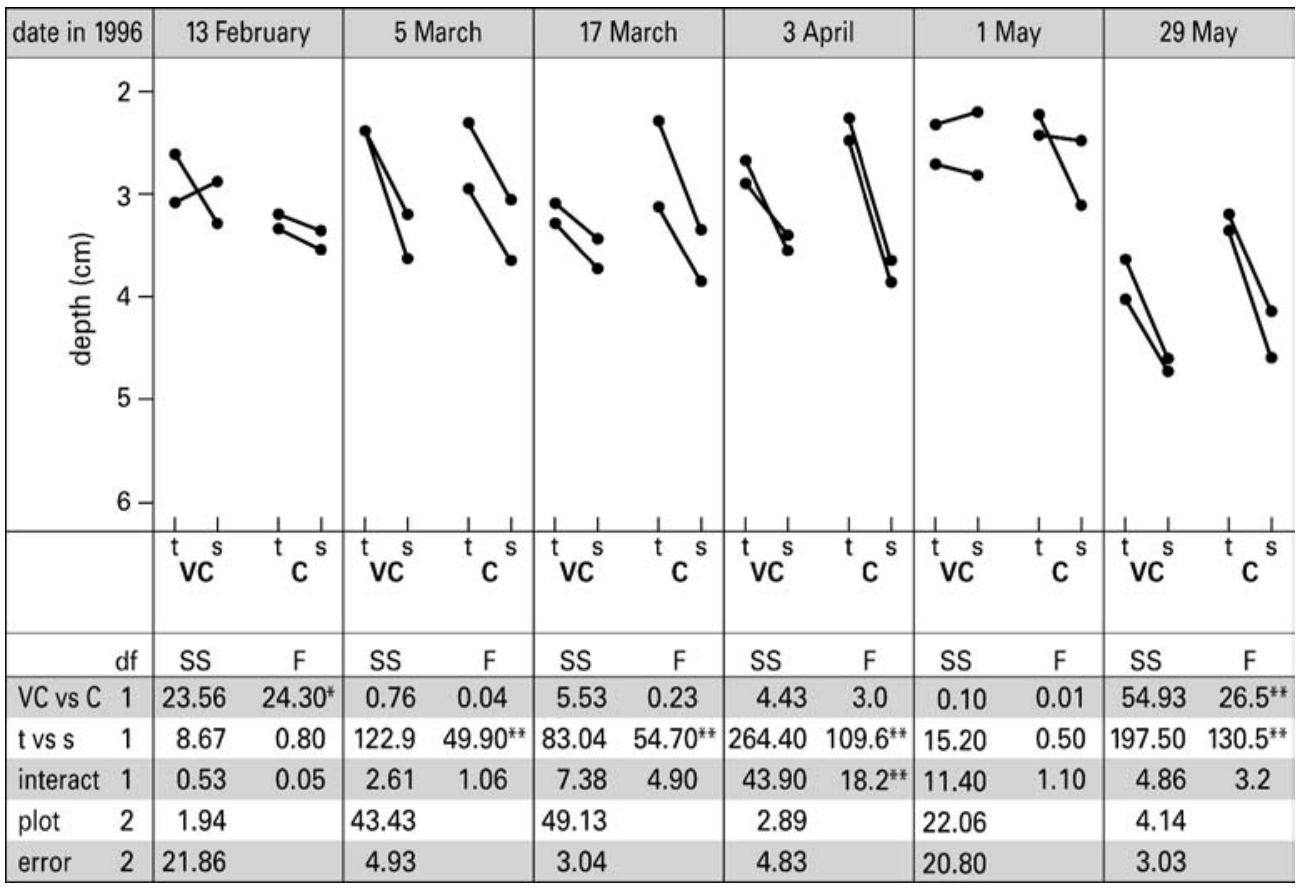

Fig. 4 Changes in gonad indices of Macoma balthica in the experimental set-up. Mean gonad indices of 15 animals per plot per treatment were plotted. Each line connects the gonad index of the intertidal and subtidal group for each plot. For each sampling day the temperature ( $V C$ very cold, $C$ cold) and the immersion treatment $(t$ intertidal, $s$ subtidal) are indicated. The $Y$-axis shows the gonad index. Below each part of the figure, ANOVA results are given. Significance levels are shown as ** if $P<0.05$ and * if $P<0.10$

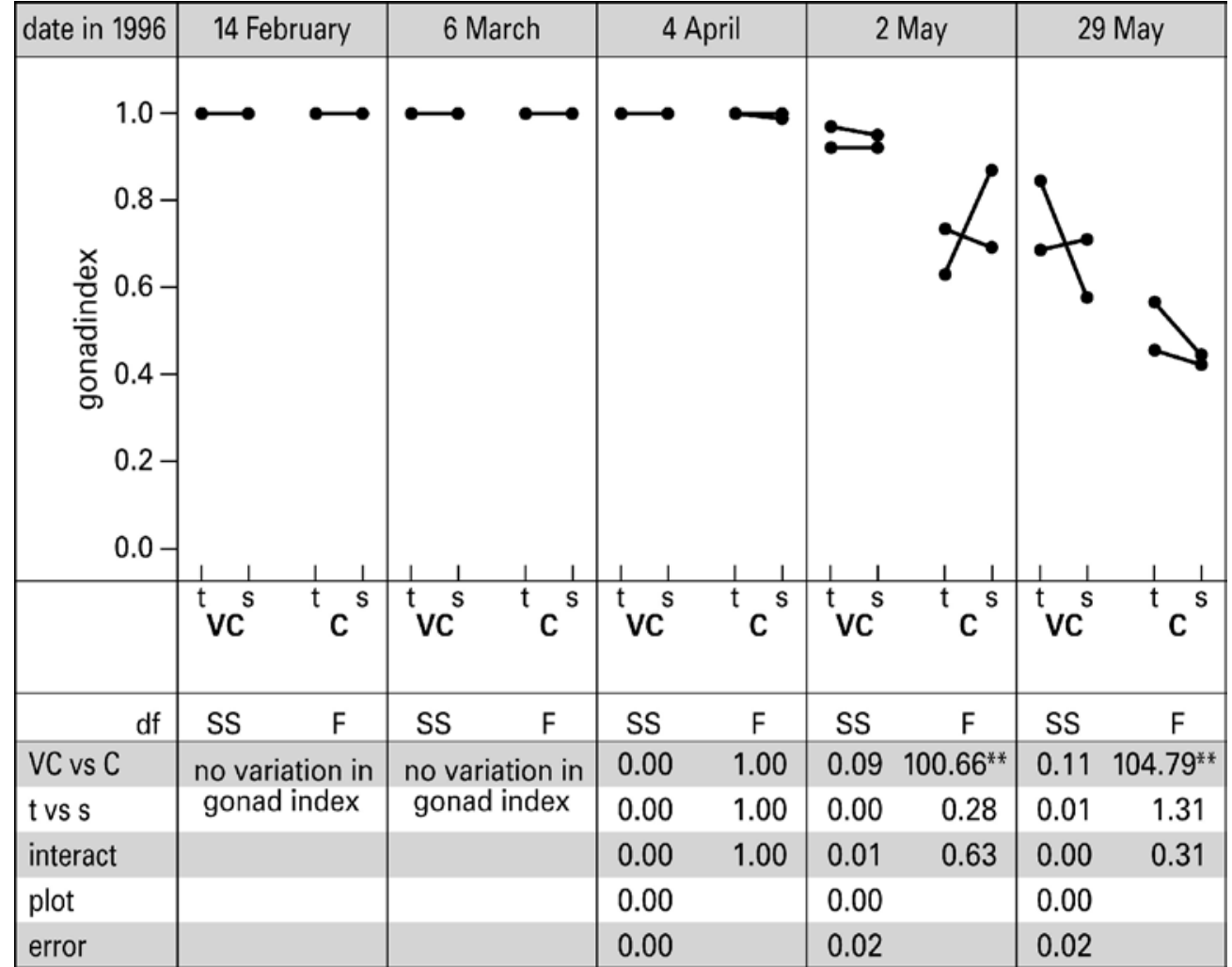

The effect of immersion time on body mass index, burying depth and gonadal development

Only in late spring, from 2 May onwards, were significant effects of immersion time on body mass observed. $M$. balthica subjected to subtidal conditions generally had larger body masses than $M$. balthica subjected to tidal conditions (Fig. 2). Immersion time had an obvious and consistent effect on burying depth. Throughout the whole experimental period subtidally living $M$. balthica buried significantly deeper than intertidally living M. balthica (Fig. 3). The general pattern in burying depth is one of constant depth until the beginning of April. In April M. balthica come closer to the surface 
until the beginning of May, when they bury deep again. Immersion time had no effect on the gonadal development or the moment of spawning (Fig. 4).

\section{Discussion}

The effect of temperature on BMI, burying depth and gonads

\section{Body mass index}

Under our experimental regimes $M$. balthica did not lose mass during the winter period and in winter BMI did not differ between temperature treatments. This is in contrast with a similar experiment, in which $M$. balthica subjected to high winter water temperatures $\left(5.6^{\circ} \mathrm{C}\right.$ and $\left.3.1^{\circ} \mathrm{C}\right)$ lost body mass in February and March (Honkoop and Beukema 1997). M. balthica incur lower metabolic costs at lower temperatures (Honkoop and van der Meer 1997). It is possible that our experimental winter temperatures were so low that $M$. balthica in both treatments had the same energy expenditure in their dormant winter state. The prediction that with a colder winter temperature, a higher body mass in spring would be found (Beukema 1992; Zwarts 1991; Honkoop and Beukema 1997), also could not be confirmed.

When temperatures increased dramatically in April, BMI of M. balthica started to increase also. This pattern is congruent with the data of Beukema et al. (1985) who found that most of the yearly mass increase in $M$. balthica occurred at water temperatures between $4^{\circ} \mathrm{C}$ and $16^{\circ} \mathrm{C}$. Also in late spring there were no differences in BMI between animals in the two temperature treatments, perhaps because food was already abundant enough to compensate for possible temperature-induced variance in energy expenditure.

\section{Burying depth}

On most experimental dates temperature differences were not correlated with differences in burying depth. We predicted that colder water would indirectly lead to deeper burying through higher body condition of $M$. balthica. Since we found no difference in BMI between temperature treatments either, this prediction can neither be confirmed nor rejected.

\section{Gonads}

It is known that during the coldest periods during winter, generally in January and February, gonadal development can cease (Bayne 1984) and resume, as temperatures become higher. At higher water temperatures, metabolic demands are higher and more eggs will be resorbed than at lower temperatures (Honkoop and van der Meer 1998). Since BMI values did not differ during the winter it seems logical that gonad indices also did not differ. However, our gonad indices are qualitative and cannot be compared with counts of eggs as in Honkoop and van der Meer (1997).

It was expected that spawning would start at water temperatures of $10^{\circ} \mathrm{C}$ and higher (Lammens 1967; de Wilde and Berghuis 1978). This temperature would be reached earlier in the 'cold' basins and therefore spawning should start earlier in the 'cold' treatment. Indeed, spawning started earlier in the 'cold' basins than in the 'very cold' basins, and lasted for at least 3 weeks. Thus spawning is not entirely synchronized, which is consistent with the field data of Caddy (1967), Lammens (1967) and J. Drent and P.C. Luttikhuizen (unpublished), who showed that multiple spawning events take place over a period of many weeks. As M. balthica stretch out much of their exhalent siphon into the water column during spawning, we expected burying depth to be influenced by the very event of spawning. That very shallow burying of $M$. balthica coincided with the start of spawning is congruent with this expectation, but the observation that $M$. balthica reburied to greater depths while there were still spawning events to come, contradicts the hypothesis. When we looked at individual M. balthica, those that were still full of gonads also buried deeper in May. Perhaps, an endogenous circannual clock (Gwinner 1986) primarily drives burying depth in spring.

The effect of immersion time on BMI, burying depth and gonads

\section{Body mass index}

We expected longer immersion times to lead to longer feeding times and higher BMI (Beukema et al. 1977; Cadée and Hegeman 1977; Hummel 1985; Honkoop and Beukema 1997; de Goeij and Honkoop 2002). Longer immersion periods did indeed lead to higher body masses of $M$. balthica from 4 April onwards, but the difference in body mass was only significant on 3 and 29 May. This may be an effect of different energetic demands during the experimental period. At the beginning of spring, metabolic costs were low because of low water temperatures (Honkoop and van der Meer 1997). As soon as temperatures started to increase, metabolic costs increased and so did the food requirement of $M$. balthica. This suggests that it be due to shortage of food that the bivalves in the tidal basins lagged behind in growth.

\section{Burying depth}

We also expected an effect of immersion time on burying depth (Lin and Hines 1994; Honkoop and Beukema 1997; de Goeij and Honkoop 2002); as the longer the immersion period would be, the longer the period for feeding would be and the deeper M. balthica could bury to increase safety. On most sampling dates, longer immer- 
sion time indeed led to deeper burying. However, with the possible exception of 29 May, such an effect of immersion time on burying depth was not correlated with a higher body mass. The effect of immersion time on burying depth must therefore be a 'direct effect'; it leads to deeper burying independent of body condition.

M. balthica that were experimentally forced to remain deep in early spring starved (de Goeij and Luttikhuizen 1998). The advantage of shallower burying is that during suspension-feeding it leads to lower pumping costs through the siphon (Zaklan and Ydenberg 1997) and during deposit-feeding the feeding radius is greater (Zwarts et al. 1994). It seems that $M$. balthica can compensate for loss of feeding time by burying shallowly.

\section{Gonads}

We predicted that longer immersion time would lead to higher body masses in winter, and in turn this would lead to larger gonads in spring (Honkoop and van der Meer 1997). However, as body masses at the end of the winter did not differ, the lack of a difference in the development of the gonad index and the timing and extent of loss of gonadal tissue did not come as a surprise. Time course of spawning did not show any tidally related differences.

\section{Conclusions}

The aim of this research was to gain more insight into the factors that influence burying depth (accessibility) of the bivalve $M$. balthica, for predators such as the red knot. It was already known that body condition and siphon length (Zwarts and Wanink 1989, 1991) affect their accessibility. The present experiment shows that immersion time also affects burying depth. It was expected that the effect of immersion time would work indirectly through the body condition of $M$. balthica (Zwarts and Wanink 1991; de Goeij and Honkoop 2002). Longer immersion time would lead to more time for feeding and result in a higher body condition score. The better the body condition, the deeper M. balthica would bury. However, it is now clear that immersion time has a direct effect on burying depth independent of body condition.

It was also expected that winter water temperatures would affect burying depth indirectly through body condition (Honkoop and Beukema 1997). We could not find a difference in body condition or burying depth as a result of different winter water temperatures. However, this is most probably the result of extremely low temperatures during the winter in which we carried out the experiment. The third expectation was that the timing of spawning would affect burying depth of M. balthica. This was not the case.

To be able to predict the accessibility of $M$. balthica to different predators, it is still necessary to experimen- tally test the relationship between body condition and burying depth, for example by starving the bivalves and by following their burying depth. That immersion time influences burying depth directly means that at different localities on the intertidal flats (with different immersion times), burying depth of $M$. balthica will be very different. This has to be taken into account when predictions are made about the accessibility of $M$. balthica for probing predators.

Acknowledgments We want to thank IBN/DLO/Alterra for the use of their experimental facilities, Hendrik van Aken for providing Marsdiep-inlet water-temperature data, Gerhard Cadée and Jan Hegeman for providing chlorophyll- $a$ data, Theo Kuip and Robert Lakeman for technical help, Jan Bruin, Diana Kwast, Ciska Raaijmakers and Jaco van der Spek for help with collecting the Macoma balthica and analysing samples, Kees Camphuijsen for breaking the ice during the cold spell, Jaap van der Meer for help with the statistical analysis, and Jan Drent, Pim Edelaar, Graciela Escudero, Theunis Piersma and Yvonne Verkuil for fruitful discussions and for reading successive drafts. The experiments comply with the current laws of the Netherlands. This is NIOZ publication 3661 .

\section{References}

Bayne BL (1984) Aspect of reproduction in bivalve molluscs. Adv Invertebr Reprod 3:357-366

Beukema JJ (1992) Expected changes in the Wadden Sea benthos in a warmer world: lessons from periods with mild winters. Neth J Sea Res 30:73-79

Beukema JJ, Cadée GC, Jansen JJM (1977) Variability in growth rate of Macoma balthica (L.) in the Wadden Sea in relation to availability of food. In: Keegan BF, O'Ceidigh P, Boaden PJS (eds) Proceedings of the 11th European marine biology symposium. Pergamon, New York, pp 69-77

Beukema JJ, Knol E, Cadée GC (1985) Effects of temperature on the length of the annual growing season in the tellinid bivalve Macoma balthica (L.) living on tidal flats in the Dutch Wadden Sea. J Exp Mar Biol Ecol 90:129-144

Caddy JF (1967) Maturation of gametes and spawning in Macoma balthica (L.). Can J Zool 45:955-965

Cadée GC, Hegeman J (1977) Distribution of primary production of the benthic microflora and accumulation of organic matter on a tidal flat area, Balgzand, Dutch Wadden Sea. Neth J Sea Res 11:24-41

Cochran WG, Cox GM (1957) Experimental designs, 2nd edn. Wiley, New York

Goeij P de, Honkoop PJC (2002) The effect of immersion time on burying depth of the bivalve Macoma balthica (Tellinidae). J Sea Res 47:109-119

Goeij P de, Luttikhuizen PC (1998) Deep-burying reduces growth in intertidal bivalves: field and mesocosm experiments with Macoma balthica. J Exp Mar Biol Ecol 228:327-337

Gwinner E (1986) Circannual rhythms: endogenous annual clocks in the organization of seasonal processes. Springer, Berlin Heidelberg New York

Honkoop PJC, Beukema JJ (1997) Loss of body mass in winter in three intertidal bivalve species: an experimental and observational study of the interacting effects between water temperature, feeding time and feeding behaviour. J Exp Mar Biol Ecol 212:277-297

Honkoop PJC, Meer J van der (1997) Reproductive output of Macoma balthica populations in relation to winter-temperature and intertidal-height mediated changes of body mass. Mar Ecol Prog Ser 149:155-162

Hulscher JB (1973) Burying-depth and trematode infection in Macoma balthica. Neth J Sea Res 6:141-156 
Hummel H (1985) Food intake of Macoma balthica (Mollusca) in relation to seasonal changes in its potential food on a tidal flat in the Dutch Wadden Sea. Neth J Sea Res 19:52-76

Lammens JJ (1967) Growth and reproduction of a tidal flat population of Macoma balthica (L.). Neth J Sea Res 3:315-382

Lin J, Hines AH (1994) Effects of suspended food availability on the feeding mode and burial depth of the Baltic clam, Macoma balthica. Oikos 69:28-36

Reading CJ, McGrorty S (1978) Seasonal variations in the burying depth of Macoma balthica (L.) and its accessibility to wading birds. Estuar Coast Mar Sci 6:135-144

SPSS (1997) SYSTAT 7.0 for Windows. SPSS, Chicago

Wilde PAWJ de, Berghuis EM (1978) Laboratory experiments on the spawning of Macoma balthica: its implications for production research. In: McLusky DS, Berry AJ (eds) Physiology and behaviour of benthic organisms. Pergamon, Oxford, pp 375384

Zaklan SD, Ydenberg R (1997) The body size-burial depth relationship in the infaunal clam Mya arenaria. J Exp Mar Biol Ecol 215:1-17
Zwarts L (1986) Burying depth of the benthic bivalve Scrobularia plana (Da Costa) in relation to siphon-cropping. J Exp Mar Biol Ecol 101:25-39

Zwarts L (1991) Seasonal variation in body weight of the bivalves Macoma balthica, Scrobicularia plana, Mya arenaria and Cerastoderma edule in the Dutch Wadden Sea. Neth J Sea Res 28:231-245

Zwarts L, Wanink JH (1989) Siphon size and burying depth in deposit- and suspension feeding benthic bivalves. Mar Biol 100:227-240

Zwarts L, Wanink JH (1991) The macrobenthos fraction accessible to waders may represent marginal prey. Oecologia 87:581587

Zwarts L, Wanink JH (1993) How the food supply harvestable by waders in the Wadden Sea depends on the variation in energy density, body weight, biomass, burying depth and behaviour of tidal-flat invertebrates. Neth J Sea Res 31:441-476

Zwarts L, Blomert A-M, Spaak P, Vries B de (1994) Feeding radius, burying depth and siphon size of Macoma balthica and Scrobicularia plana. J Exp Mar Biol Ecol 183:193-212 